Preliminary and incomplete

\title{
Government Failure vs. Market Failure: Principles of Regulation
}

\author{
Joseph E. Stiglitz
}

The subject of regulation has been one of the most contentious, with critics arguing that regulations interfere with the efficiency of the market, and advocates arguing that well designed regulations not only make markets more efficient but also help ensure that market outcomes are more equitable. Interestingly, as the economy plunges into a slowdown, if not a recession, with more than 2 million Americans expected to lose their homes (unless the government intervenes), there is a growing consensus: there was a need for more government regulation. Responding to these calls - as if to close the barn door after all the horses have gotten out-the Federal Reserve has tightened some regulations. If it is the case that better regulations could have prevented, or even mitigated, the downturn, the country, and the world, will be paying a heavy price for the failure to regulate adequately. And the social costs are no less grave-as hundreds of thousands of Americans will not only have lost their homes but their lifetime savings. Home ownership has long been thought of as contributing to the strength of communities; with the share of home ownership falling, communities too will be weaker. The foreclosures will exacerbate the decline in housing prices, and property tax bases will erode - a further knock on effect of inadequate regulation.

When Upton Sinclair's novel The Jungle depicted the terrible sanitary conditions in America's stock yards, Americans turned away from meat; and the meat packing industry asked for government food safety regulation to restore confidence. When the Enron/WorldCom scandal eroded confidence in America's financial markets and accounting firms, there was again a demand for stronger regulation to restore confidence. Whether Sarbanes-Oxley went too far or not far enough may be debated; but what is not debatable is that such regulations were viewed, at least by many Americans, as essential for restoring confidence in America's markets, where scandal had touched every accounting firm, most of the major investment banks, and many of its leading corporations.

Today, America's air and water is cleaner—and Americans are living longer-because of environmental regulations. No one can imagine a world today without food, safety, and environmental regulations. The debate is only whether we have gone too far, and whether we could have gotten the desired results at lower costs.

\footnotetext{
${ }^{*}$ University Professor at Columbia University and chair of its Committee on Global Thought; Chairman of the Brooks World Poverty Institute at Manchester University; and President of the Initiative for Policy Dialogue (on the web at http://www.policydialogue.org). Financial support from the UNDP and Ford, Macarthur, and Rockefeller Brothers Foundations is gratefully acknowledged. This paper was prepared for the Tobin Project's conference on "Government and Markets: Toward a New Theory of Regulation," held February 1-3, 2008, in Yulee, Florida.
} 
In this paper, I want to outline the principles underlying the modern theory of regulation. Section I presents the rationale for regulation-why regulation is required. Section II discusses the forms that regulation can and should take. Section III applies these principles to three subjects of current concern: sovereign wealth funds, financial market regulation, and environmental regulations directed at greenhouse gases.

\section{The General Theory of Regulation}

The general theory of regulation begins with a simple question: Why is regulation needed? This is, in turn, divided into two sub-questions: Why do markets by themselves not suffice? And if there is to be government intervention, why does it take the form of regulations?

\section{a. The need for government intervention}

i. conventional market failures

Adam Smith (it is widely believed) argued that markets by themselves are efficient. ${ }^{2}$ Arrow and Debreu established the sense in which that was true (Pareto efficiency, i.e. no one could be made better off without making someone else worse off), and the conditions under which it was true (perfect competition, no externalities, no public goods). ${ }^{3}$ Subsequently, Greenwald and Stiglitz showed that whenever information is imperfect or markets incomplete - that is, always - there is a presumption that markets are not (constrained) pareto efficient. ${ }^{4}$ Thus, the notion that markets, by themselves, lead to efficient outcomes has, today, no theoretical justification: no one believes that the conditions under which that statement is true are satisfied.

Some advocates of free markets take it as a matter of faith that the magnitude of the inefficiencies are small (though no one has suggested how one might prove that); but more commonly advocates of free markets take it as a matter of faith that government attempts to correct market failures by and large make things worse. To be sure, there are examples of badly designed government regulations, but the disasters associated with

\footnotetext{
${ }^{2}$ Actually, his analysis was far more subtle than modern free market economists would have one believe.

${ }^{3}$ See K.J. Arrow, "An Extension of the Basic Theorems of Classical Welfare Economics," Proceedings of the Second Berkeley Symposium on Mathematical Statistics and Probability, J. Neyman, ed., Berkeley: University of California Press, 1951, pp. 507-532, and Gerard Debreu, The Theory of Value, New Haven: Yale University Press, 1959.

${ }^{4}$ See Bruce Greenwald and J. E. Stiglitz, "Externalities in Economies with Imperfect Information and Incomplete Markets,” Quarterly Journal of Economics, 1986, Vol. 101, No. 2 (May), pp. 229-264.

Reprinted in Economic Theory and the Welfare State, Nicholas Barr (ed.), Cheltenham, UK: Edward Elgar, 2000.
} 
unfettered markets at least provide a prima facie case for the desirability of some regulation. ${ }^{5} 6$

Some advocates of free markets appeal to Coase's conjecture (sometimes called Coase's theorem) that, even in the presence of externalities, individuals can bargain themselves to an efficient outcome, so long as there are clearly defined property rights. But such claims cannot be supported so long as there is imperfect information (e.g. concerning individual's valuation of the external costs) or transactions costs, as there always are. Indeed, one of the standard arguments for regulation is that it economizes on transactions costs.

A variant of Coase's argument is that those injured should (be entitled to) sue those who are doing the injury. With a good tort legal system (including class action suits), individuals will have appropriate incentives. Interestingly, conservatives (like those in the Bush Administration) argue both for less regulation and reduced capacity to recover damages. They sometimes have a valid argument against the legal system: as currently constituted, in many areas it provides "excessive" recovery-providing excessive incentives for care-at the same time that in other areas it provides insufficient incentives (without class actions, the transactions costs are so large that recovery of damages is impossible).

More generally, sums required to compensate for damage done to individuals may not provide appropriate incentives; by linking the two together, incentives are not in general optimized. Moreover, in many cases, there is no adequate monetary incentive: someone whose child has died as a result of lead poisoning can never really be adequately compensated. Ex post compensation is not enough. We have to stop the bad behavior ex ante, if we can.

Other forms of market mechanisms, it is now realized, also are insufficient-reputation mechanisms help but do not ensure efficiency.

Regulations can thus play an important role in addressing market failures.

There are several particular categories of market failures to which I want to call attention. We have regulations designed to mitigate the extent of externalities. These include, for instance, zoning restrictions and environmental regulations. We have regulations designed to maintain competition (restrictions on anti-competitive practices), and to ensure that natural monopolies do not abuse their monopoly position (utilities regulations). We have a large set of regulations aimed at protecting consumers (ensuring

\footnotetext{
${ }^{5}$ Many economists have donned the hat of a political scientist, arguing that political processes are inherently inefficient. But there is no general theorem asserting the inevitability of "government failures" outweighing market failures, and no persuasive "counterfactual" analysis contrasting what a world without regulation might look like as compared to the current regime.

${ }^{6}$ In addition, in financial markets, where it is the regulated sector (banking) which has so often been the source of problem, some have argued that it is government regulation which is the source of the problem. What is true is that the interaction between the regulated and unregulated parts of this sector open up opportunities for regulatory arbitrage and present a special set of challenges for regulators.
} 
that the banks where they deposit their money are sufficiently sound, that food and products are safe, or that they are not taken advantage of by unscrupulous merchants, advertising, or lenders). In several of these cases, as we shall note, disclosure is important; but the regulations go well beyond disclosure, for reasons which I explain below.

There are two further categories on which I want to comment, both related to information problems. The first concerns insurance. Private sector contractual arrangements often have what would appear to be "regulatory" structures. A fire insurance firm requires that the insured install sprinklers. Sometimes, insurance companies use the price system, i.e. they give a discount if sprinklers are installed. But sometimes they simply will not write the insurance policy if sprinklers are not installed. Many government regulations are similarly motivated: government absorbs risk, and to reduce its risk exposure, imposes constraints; it provides flood and earthquake insurance (explicitly in some cases and implicitly in others - if an earthquake occurs, it knows that it cannot deny assistance to anyone) and demands that houses be constructed so as to reduce the risk of loss. Because of moral hazard - or even because of a failure to perceive accurately the magnitude of the risk $^{7}$ —individuals will take insufficient care.

The second category concerns what might be called certification. The meatpackers wanted certification that their products were produced in a safe and humane manner. They also knew that the only credible source of such certification was the governmentif the meatpackers paid the certifiers directly, there would be a conflict of interest.

Recent troubles in accounting and rating agencies highlight the problems of private certification. The Enron scandal highlighted that the accounting firms' incentives were distorted; and while Sarbanes-Oxley improved matters, it did not fully resolve them. ${ }^{8}$ Similarly, with the rating agencies being paid by the financial firms to rate the complex products they were creating, it is perhaps no surprise that they gave AAA ratings to highly risky products.

Information is a public good. ${ }^{9}$ All individuals want to be assured that if they put money in a bank, the bank will be there when it comes time to withdraw the money. Government bank regulation is in part certification: it sets certain standards that a bank must satisfy — and inspects that it fulfills those standards. It could, of course, stop there, allowing individuals to deposit their money in "uncertified" banks (and in a sense, it does that - there are many non-certified financial institutions). But it goes beyond that: it does not allow banks to operate unless they satisfy certain conditions. And that, in part, is because it knows that if a bank fails, it may have to be bailed out. As one astute observer put it: there are two kinds of governments-those who provide deposit

\footnotetext{
${ }^{7}$ See the discussion below.

${ }^{8}$ See J. E. Stiglitz, Roaring Nineties, New York: WW Norton, 2003.

${ }^{9}$ This is a theme to which I will return. We have already discussed the incentive problems which arise when the seller pays for certification. In most cases, it is hard to design systems where the buyer pays for certification; others, observing the behavior of those who have purchased the information, can free ride.
} 
insurance and know it; and those who do so and don't know it. ${ }^{10}$ This in turn means that in order to mitigate the moral hazard problem, restrictions on banks have to be imposed.

\section{ii. Irrationality}

The market failure approach growing out of an analysis of the standard assumptions required to establish the Pareto efficiency of the economy (the First Fundamental Theorem) is, however, only one of at least three strands of analysis underlying the demand for regulation. A second focuses on market irrationality. The standard competitive equilibrium model assumed that all individuals were rational; it explained why rational individuals (households) interacting with profit (or value) maximizing firms in a competitive marketplace might not result in Pareto efficient allocations. But individuals may not be rational and may deviate from rationality in systematic ways. Individuals (and even more so societies) have to be saved from themselves. Markets suffer from irrational exuberance and irrational pessimism. Individuals may not save adequately for their retirement.

Until the recent work on behavioral economics, economists typically looked askance at such paternalistic arguments for government intervention. Why, it was argued, should there be any presumption that governments are more rational or better informed than individuals? Who are we to impose our beliefs of what is rational on others? Part of the answer was provided by the classic theory of market failure: one might argue that so long as the individual only harms himself, there is no reason for government intervention. But individual actions may adversely affect others (there are, in effect, externalities). Regulation may reduce the likelihood of these adverse effects occurring and their impacts when they do.

There is a special category of externalities that arises in democratic societies. Societies cannot stand idly by when it sees someone starving-even if it is a result of the individual's own mistakes, say, not saving enough. Society will bail out the individual (or a bank which is too big to fail). Knowing that, individuals have an incentive to save too little (or banks to take too much risk). Knowing that, government should impose regulations to ensure that individuals do save enough (or banks do not undertake excessive risk).

But the new behavioral economics puts a new perspective on these issues: individuals may, in some sense, be better off if they are compelled to undertake some actions or are circumscribed from undertaking others. A potential alcoholic or drug addict may realize that he may be tempted to consume these toxic products and then become addicted. He knows before he becomes addicted that he will regret getting the addiction, but once he is

\footnotetext{
${ }^{10}$ Some have argued that deposit insurance gives rise to a moral hazard problem-depositors take less care in inspecting the credit worthiness of the banks in which they put their money. But because information is a public good, it is inefficient for each individual to gather and process this information. Indeed, it is virtually impossible for them to do so. If individuals did that, they would have no time to make money to put into the bank. They can hire services (credit rating agencies) to evaluate the banks in which they deposit their money, but there are well known market failures in these markets.
} 
addicted, will not be able to change his behavior. He therefore wants the government (or someone else) to make it impossible, or at least more difficult, to become addicted. (Matters are made worse by the fact that there are firms, such as those in the tobacco industry, who profit by taking advantage of addiction. By increasing the addictive properties of their products, they reduce the elasticity of demand and increase profitability.)

Similarly, individuals may know that they can easily be induced to save very little or a great deal, simply on the basis of the default set by the employer in choosing the fraction of income to put into a savings account. Accordingly, they might want the government to force the firm to undertaken a kind of analysis that sets the default rate in ways which enable the individual to have a reasonably comfortable retirement, without sacrificing excessively current levels of consumption.

A formal welfare analysis of such regulations within the traditional welfare economics paradigm is, of course, difficult: do we evaluate the impacts of the policy intervention using individuals' ex ante expected utility (their incorrect beliefs, for instance, about the consequences of their actions), or using ex post realized (average) utility?

iii. Distributive justice

There is a third category of rationale for government interventions: the best that can be said for the market economy is that it produces efficient outcomes; there is no presumption that it produces outcomes that are viewed as socially just. Regulations may be an important instrument for achieving distributive objectives, especially when governments face tight budgetary constraints (or other administrative constraints). CRA (Community Reinvestment Act) lending requirements or health insurance mandates may be an effective way of helping poor individuals when the government cannot afford other ways of helping them. ${ }^{11}$

\section{b. Regulations vs. other forms of intervention}

Critics of regulation argue the objectives of regulation can be achieved better at lower costs by using "market based" interventions, i.e. taxes and subsides. If smoking gives rise to an externality, tax smoking. If greenhouse gases give rise to global warming, tax greenhouse gas emissions. Price interventions have much to commend them: they are general, simple, and often have low transactions costs. But research over the last quarter century has clarified an important set of limitations. Indeed, the very conditions (such as imperfect and asymmetric information) that imply that markets by themselves do not in

\footnotetext{
11 Typically economists argue that a Pareto improvement could be achieved, e.g. by imposing taxes and providing subsidies for health insurance for the poor. But there are deadweight losses associated with raising taxes, and it may be harder to target the subsidies very well. Here we are concerned with the rationale for government intervention. Later, we shall discuss at greater length the relative merits of different forms of intervention.
} 
general lead to (constrained) Pareto efficient outcomes also imply that price interventions by themselves will not suffice. ${ }^{12}$

\section{i. Imperfect information and incomplete contracting}

Most importantly, in the presence of imperfect information and incomplete contracting, optimal incentive schemes typically are highly non-linear (they do not take the form of a price intervention) and may even impose constraints (like rationing and terminations). ${ }^{13}$

In a sense, most regulations can be recast as (typically simple) forms of non-linear price schedules; but few price schedules, used in the private or public sector, are in fact anywhere near the complexities of those that emerge from optimal incentive schemes. Whether a particular regulatory structure is better or worse than a particular simplified non-linear price system may be hard to ascertain; and in any case, viewed through lens, the distinction between regulatory systems and (non-linear) price systems is morel a matter of semantics than anything else.

There is, of course, a literature contrasting polar forms: a pure price system or a pure quantity (regulatory) system. But there is seldom reason to resort to such extremes, and in many cases, the standard formulation is simply not relevant.

\section{ii. $\quad$ Prices vs. quantities}

Nonetheless, much of the literature has been couched in exactly these extremes. ${ }^{14}$ It has been argued, for instance, that, depending on the nature of the shocks (to the demand and supply curves), quantity interventions (regulations) may lead to a higher level of expected utility than price interventions. ${ }^{15}$

Consider, for instance, the problem of greenhouse gases. Some have suggested that this is a classic case where quantity regulation is to be preferred. With price interventions, the

\footnotetext{
${ }^{12}$ For a broad discussion of this perspective, particularly in the context of regulations for natural monopolies, see D. Sappington and J. E. Stiglitz, "Information and Regulation," in Public Regulation, E. Bailey (ed.), London: MIT Press, 1987, pp. 3-43.

${ }^{13}$ Much of the discussion below views the problem of regulation through the lens of principal-agent problems. The fundamental problem is that the regulator has imperfect information about the firm that it wishes to regulate, e.g. its costs, or even its behavior. It can affect behavior (and thereby outcomes) by controlling or otherwise affecting through incentives those things which are observable, which may include processes (what the firm produces and how it produces it), precluding some actions, mandating others, subsidizing some observable inputs or outputs, taxing others, etc. Changing information that is available affects, of course, the nature of the principal-agent problem, including the optimal incentive structures. Many of the problems being considered here may be viewed as "layered" principal-agent problems; the regulator is ultimately interested in the well-being of consumers, but he is simultaneously trying to affect directly the behavior of firms, and indirectly, through effects on the behavior of other agents in society (consumers, investors).

${ }^{14}$ Of course, there are some forms of behavior which are not easily amenable to simple price interventions, e.g. anti-competitive behaviors, though fines and other penalties can be an important part of an incentive scheme to induce firms not to behave in an anti-competitive manner.

${ }^{15}$ See, in particular, M. Weitzman, "Prices vs. Quantities," The Review of Economic Studies, 41(4), October 1974, pp. 477-491.
} 
level of greenhouse gas emissions is uncertain; a change in the demand or supply curve will mean that we will have less or more emissions than is desirable.

But the argument is hardly persuasive: global warming is related to the level of concentration of greenhouse gases in the atmosphere, and what matters for this is not the level of emissions in any particular year. There is, in fact, even some uncertainty about the relationship between emission levels and changes in concentration levels and about the relationship between the level of concentration of greenhouse gases and the (precise) change in climate. There will have to be, in any case, adjustments to the allowable levels of emissions over time. Using prices (emission taxes), there will have to be adjustments too, with one additional factor of uncertainty: the relationship between taxes and emissions. But provided that adjustments are made in a relatively timely way, there is little additional risk in the variables of concern, the level of concentration of greenhouse gases, and climate change.

But there are contexts in which regulations may be better than price interventions. If import supply functions are highly variable but domestic demand and supply conditions do not vary, then setting a tariff leads to high variability in price, domestic output and production; setting a quota eliminates this costly source of "imported" risk. Tariffication (shifting from quotas to tariffs) may, accordingly, not be welfare enhancing. ${ }^{16}$

In general, with imperfect information (and incomplete contracting) it is optimal to use a complex set of "controls” which entail both (generalized) incentives and constraints.

\section{c. Instruments of regulation}

Regulation takes on a number of forms: information requirements, proscriptions (things firms may not do), or mandates (things firms must do).

\section{i. Disclosure}

Recent discussions have favored information requirements. Who can object to more transparency or better information? (Actually, hedge funds, and their representatives in Treasury, have objected: they have argued that those investing in information need to get a return on their investments; if they disclose what they do, they are, in effect, giving this asset away. Some of the same individuals who made this argument in connection with hedge funds are now demanding more transparency for sovereign wealth funds, even when these funds invest heavily in research.)

Market forces do not necessarily lead to full (or efficient) disclosure of information, so there is a good rationale for disclosure requirements. Markets cannot function well with distorted and imperfect information; hence, requirements that lead to improved information can (by and large) lead to better resource allocations.

\footnotetext{
${ }^{16}$ See P. Dasgupta and J.E. Stiglitz, “Tariffs Versus Quotas As Revenue Raising Devices Under Uncertainty,” American Economic Review, 67(5), December 1977, pp. 975-981.
} 
The design of disclosure requirements, however, often entails more complex issues than one might have thought. The disclosure of a chemical substance in a product may be interpreted as prima facie evidence that its presence is dangerous, even when there is no scientific evidence that that is the case. Disclosures may be done in ways which in fact do not "alert" consumers to risks when they are there. That is why the form of cigarette warnings has been tightly regulated. All investment prospectuses describe a large number of risks which the investor may face-they are fully disclosed but in ways that may not be helpful in distinguishing the level of risk.

Disclosures concerning stock options, which dilute shareholder value, are still done in a manner which does not convey the relevant information to most shareholders in an effective way. Those companies (and those who work with them) have lobbied strongly and so far successfully against such disclosure requirements. There are technical details in calculating the value of the dilution, but what is clear is that assigning a zero value is incorrect.

Disclosure of potential conflicts of interest, ownership, or remuneration may help market participants "interpret" the actions of others. For instance, knowing that a salesman gets a higher commission from selling one product than another may shed some light on his praise of the product generating higher commissions; knowing that analysts' pay is not related to the accuracy of their prediction of stock performance but to the investment deals they bring in sheds some light on the reliability of their forecasts; knowing that CEO's are remunerated on the basis of reported earnings may affect judgments about the reliability of those reports; and knowing the structure of remuneration of hedge fund managers should lead to an expectation that they will engage in excessive risk taking.

Disclosure requirements seem less invasive than other regulations, such as the restrictions and mandates to be described below, but it should be clear that in many areas, disclosure itself does not fully address the market failures discussed earlier. This is partly because market participants do not know how to process fully the information which has been disclosed and partly because even if market participants know what firms are doing, firms may still not behave appropriately. Citizens may put pressure on firms that have been disclosed to be polluting the atmosphere-disclosure has been shown to have some effects on some firms - but some firms continue to pollute excessively. And there are some firms that are willing to take advantage of individuals who remain uninformedeven when the information is potentially available, for instance, by producing unsafe products. That is why regulations entail restrictions and mandates.

\section{ii. Restrictions}

The most direct restrictions are proscriptions on behaviors: firms are not allowed to collude in price setting or to engage in other anti-competitive practices, banks are not allowed to engage in insider lending. 
The latter is an illustration of a general principle: one would like to be able to tell banks only to give "good loans" and not to give preferential treatment to one's friends. But regulators cannot tell what is a good or a bad loan. They can only tell when there might be distorted incentives. Regulation thus often focuses not on behaviors so much as on factors that might affect behaviors. It attempts to proscribe conflicts of interest (e.g. recent restrictions on accounting firms), or to ensure that the firm has enough wealth not to act in a reckless way ${ }^{17}$ (for instance, capital requirements on banks and airlines). Proposed restrictions on sovereign wealth funds fall in this category (see the discussion below).

A critical issue is the specificity of the restrictions. The economy is constantly changing; this is particularly so in the financial sector. Financial innovators will figure out a way of getting around any set of regulations - and, in what has come to be called regulatory arbitrage, make a great deal of profits in doing so. In some states, laws and regulations have been passed (like the Martin Act) that have a broad target, recognizing that the specific means by which these "anti-social" objectives can be achieved will change. In return for the lack of specificity in actions, the punishments are more muted: fines which will recapture the ill-gotten gains rather than prison terms. It was these laws that were among the most effective in addressing the series of scandals in which financial firms were involved in the late 90s and early years of this decade, including those involving analysts, stock options, the investment banks, and CEO's.

Similar issues have arisen in anti-trust. Firms have been extraordinarily clever in devising ways of reducing competition. If regulators impose restrictions on particular behaviors, monopolies will innovate to find new ways of acting anti-competitively that are consistent with the rules (but obviously, against the spirit of the rules). The only way to reduce the scope for such anti-competitive behavior is to affect incentives, i.e. structural remedies, such as breaking up the firm or limiting the scope of intellectual property protections. ${ }^{18}$

\section{iii. Mandates}

Mandates have increased in popularity because they enable the accomplishment of public purposes without the expenditure of money. But as critics point out, they are often a hidden form of taxation, though the incidence of the tax is often difficult to assess, and the tax/expenditure programs that are "implicit" are often inefficient and inequitable. Several candidates are now considering health mandates, requiring all firms to provide health insurance to their employees.

Yet, some mandates may be viewed as efficient ways of addressing complex societal problems involving externalities. The CRA requirements have arguably expanded access to finance for minorities, and many banks today claim that—after paying the initial costs

\footnotetext{
${ }^{17}$ Bankruptcy means in effect that even risk averse owners/managers may behave in a risk loving way.

${ }^{18}$ See, e.g. Jason Furman and J. E. Stiglitz, "U.S. versus Microsoft, Declaration as Part of The Tunney Act Proceeding," with Jason Furman, commissioned by the Computer \& Communications Industry Association, Jan. 28, 2002
} 
of entering these markets - their returns are just as high as elsewhere. Granting a license to a bank is a privilege, with market value. Governments do not typically auction off the licenses to the highest bidder (doing so might not be the best way to get the best bankers ${ }^{19}$ ). So society engages in a kind of barter: rights (e.g. access to the Fed discount window) are exchanged for responsibilities (e.g. to lend in underserved communities). This kind of exchange has become particularly common as a part of zoning-restrictions on land usage. The lack of transparency is disturbing, offset in part by how effective it often is, particularly in the presence of budgetary constraints.

\section{iv. Ownership restrictions}

The previous subsections have described how regulations force disclosure of information (which firms might not otherwise disclose), restrict some actions, and mandate others. However, we go beyond restricting actions-partly because we often cannot easily observe actions; we observe them, or their consequences, only with a lag. Thus, we not only restrict anti-competitive actions, but we also break up monopolies because we believe it is impossible to stop them from acting in an anti-competitive way. Before the break-up of AT\&T, there was an attempt to restrict its anti-competitive actions, but when those attempts failed, it was broken up. Microsoft was not broken up, and even after it agreed not to continue acting anti-competitively, it could not resist taking advantage of its monopoly power. This was the predictable, and predicted, consequence of the failure to alter incentives (e.g. by breaking up Microsoft).

Owners of banks are not allowed to make loans to themselves. It may be because their motives are wrong: they gain, even if the government (as the insurer of deposits) is put at greater risk. But even apart from these distorted incentives, they are likely to have distorted judgments — to think that they are a better risk than they really are.

The Glass-Steagall Act of 1933 restricted commercial banks from owning investment banks and vice versa, again partially because of the potential for conflicts of interest. In discussions of the repeal of this act in the 1990s, advocates of the repeal said not to worry, they would construct Chinese Walls. But that raised the question: if these Chinese Walls were really constructed, where were the economies of scope which provided that rationale for the elimination of the restrictions? In the end, lobbying by the banks (and undoubtedly the links between Treasury and financial markets) succeeded in getting the repeal, and worries about conflicts of interest proved justified, evidenced in the ensuing Enron/WorldCom scandals.

We may feel better knowing that a company that is selling blood is doing it not-for-profit; a profit maximizing firm seeks to minimize costs, and in doing so, may buy blood from those who are desperate and unhealthy, with diseases that may not be detected. ${ }^{20}$ Many

\footnotetext{
${ }^{19}$ This is a standard problem of adverse selection. See, e.g. J.E. Stiglitz and A. Weiss, "Credit Rationing in Markets with Imperfect Information,”, American Economic Review, 71(3), June 1981, pp. 393-410

${ }^{20}$ Richard Morris Titmuss, The Gift Relationship: From Human Blood to Social Policy, New Press: New York, 1997 (reissue of 1970 book); Joel Schwartz, "Blood and altruism - Richard M. Titmuss' Criticism on the Commercialization of Blood,” Public Interest, Summer 1999.
} 
governments restrict ownership of certain key assets (such as airlines) to citizens of their country. Others recognize that there is an inevitable conflict of interest in certain areas between private owners' interests and the public interest-contrary to Adam Smith. Private firms wish to minimize what they pay for natural resources on publicly owned lands; the government wishes to maximize the return. The two interests are diametrically opposed. In a world with robust competition for resources, with perfect information, the two interests can be aligned, provided that the resources are sold in an appropriate way. But mining and oil interests will work hard to make sure that that does not occur. In these instances, public ownership may be desirable. Regulations to ensure that the private owners act in the public interest may not suffice. Indeed, more generally, social objectives can be achieved through privatization only under highly restrictive assumptions - akin to the assumptions required to ensure that competitive markets are efficient. $^{21}$

The Council of Economic Advisers opposed privatization of USEC, the government corporation charged with enriching uranium (low enriched uranium is used in nuclear power plants; highly enriched uranium is the key ingredient in nuclear bombs). We believed that private incentives for the sale of enriched uranium (and the importation of the material from deactivated warheads from Russia, to be de-enriched) did not coincide with national interests in non-proliferation, and we could not perfectly monitor their activities. The advocates of privatization (at least one of whom has now, ironically, expressed worries about the risks of Sovereign Wealth Funds) believed that we could. In the end, these anxieties turned out to be fully warranted. ${ }^{22}$

For the most part, however, we do not impose ownership restrictions, partially because we typically do not have information about ownership-some worry that gathering such information might invade individuals' right to privacy. We do not know who owns hedge funds and private equity firms, and in fact, with many owners of corporations registered abroad, ascertaining who the ultimate beneficial owner is might not be that easy. But there is another reason that we do not impose ownership restrictions: while ownership may alert us to an increased risk of behavior that is contrary to societal interests, whenever there is scope for such behavior, it needs to be restricted, whatever the motivation.

\section{d. Regulatory takings}

As we have noted, regulations (whether restrictions or mandates) can also sometimes be viewed as hidden tax/expenditure programs. The Endangered Species Act can be viewed as requiring private property owners to provide a public good-the protection of endangered species. At the time it was passed, it represented a change in property rights.

\footnotetext{
${ }^{21}$ David Sappington and J. E. Stiglitz, “Privatization, Information and Incentives,” Journal of Policy Analysis and Management, 6(4), 1987, pp. 567-582. Reprinted in The Political Economy of Privatization and Deregulation, E. Baily and J. Hower (eds.), Edward Elgar, 1993.

${ }^{22}$ For a discussion of this episode, see J.E. Stiglitz, Globalization and its Discontents, New York: W.W. Norton, 2002.
} 
Today, a repeal of the act, or providing compensation to those whose use of property is encumbered, would also represent a grant of an additional property right.

All regulations affect property values (as does anything else the government does, such as the construction of a road). Presumably, the fact that a regulation forces a firm to do something that it would not otherwise have done means that (normally) it will reduce profits. ${ }^{23}$ When property values are enhanced, no one offers to give back the increased value to the government, and those enjoying these capital gains often lobby strongly for lower tax rates. But when property values are decreased, many want compensation. Providing compensation for "regulatory takings" in a world with strong budgetary constraints greatly constrains regulation, and indeed, that is the intent of many in the regulatory takings movement. It is not just a matter of equity (say, fair compensation for the loss in value), or efficiency (say, ensuring that only regulations the value of which exceeds the costs are adopted). Courts have consistently rejected the view that regulatory takings require compensation, and with few exceptions, so have legislatures. A possible important exception is Chapter 11 of NAFTA; whether it does so remains in dispute, but wording in subsequent investment agreements has changed in response to the fear that that it might. ${ }^{24}$

The debate over regulatory takings highlights the complexity of regulatory control. As in any area of public policy, there are efficiency and distributive consequences. Economists sometimes distinguish between the Endangered Species Act, which required private parties to provide a public good, and a zoning restriction, which prevents a factory from imposing a negative externality on neighboring houses. The nature of the distributive consequences (and who bears them) depends too on the extent to which the regulation was anticipated. ${ }^{25}$

\section{e. Laws and regulations}

While we typically think of regulations in areas of environment, safety, banking, and utilities, many of the other laws affecting economic activity can be looked at through a regulatory lens. Bankruptcy laws restrict the set of contracts that parties can draw up with each other-no matter what the contract may say about what happens in the event that a debtor cannot meet his obligations, bankruptcy law will prevail if those provisions are in conflict. Similarly, corporate governance laws restrict how corporations may govern themselves.

\section{Regulatory processes}

\footnotetext{
${ }^{23}$ There are some important exceptions: some regulations are designed to prevent managers of corporations from taking actions which benefit themselves at the expense of shareholders.

${ }^{24}$ For a more extensive discussion of some of the legal and economic issues, see J. E. Stiglitz, "Regulating Multinational Corporations: Towards Principles of Cross-border Legal Frameworks in a Globalized World Balancing Rights with Responsibilities,” Grotius Lecture presented at the $101^{\text {st }}$ Annual Meeting of the American Society for International Law, Washington, D.C., March 28, 2007.

${ }^{25}$ Underlying this debate is a debate over the nature of property rights, implicit and explicit.
} 
Much of the difference between "regulation" and these areas relates to the processes by which regulations get adopted. Typically, in the case of regulations, there is some delegation: the legislature delegates authority to a regulatory agency, which is assumed to have greater expertise in addressing the complex technical issues. The delegation raises concerns about democratic accountability, particularly given the frequency with which regulatory agencies are captured by special interests. ${ }^{26}$ These concerns may not be fully obviated by legislative review processes. Regulations on how regulatory agencies design regulations (e.g. on the regulatory process) are designed to enhance democratic accountability (including transparency), but there is concern that these too have not been fully effective.

Related issues are raised by central banks, where recent doctrines have held that independent central banks lead to better performance. The evidence on that is less than compelling; what it shows is that independent central banks focusing on inflation do achieve lower rates of inflation-it would be really surprising if that were not the casebut do not succeed in achieving economically significant or even statistically significant better performance in other more relevant metrics, like growth, unemployment, or real wages. Central banks effectively control a critical price in the market, the interest rate, not so much by price regulation but by intervention. In many economies, they control a second critical price, the exchange rate. There are many doctrinal disputes over whether government should control the exchange rate, but ironically, almost none about whether government should control the interest rate (though there are many disputes about how it should control the interest rate).

The controversy over central bank independence is part of a broader debate of democratic accountability. ${ }^{27}$ One can have an independent central bank which is more broadly representative-some countries insist that there be representation of labor (which is likely to be more concerned with unemployment and less with inflation), others have limited participation of financial sector representatives. In the U.K., the government sets the inflation target; the Bank of England then has independence in how it fulfills that mandate. Independence does not necessarily mean that they have the right to operate in the non-transparent way that they traditionally have; the Bank of England has, for instance, led the way in greater transparency.

\section{f. Government Failures}

We noted the compelling case for regulation based on the fact that markets often fail, and that in principle there are government interventions that would be welfare enhancing; we noted too that in principle more than just price interventions are required. There is a need for regulation. We noted too that many of those who object argue that such an analysis

\footnotetext{
${ }^{26}$ G. Stigler, 1971. “The Theory of Economic Regulation,” Bell Journal of Economics, 2(1), Spring 1971, pp. 3-21; J.J. Laffont and J. Tirole, "The Politics of Government Decision Making: a Theory of Regulatory Capture,” Quarterly Journal of Economics, 106(4) November 1991, pp. 1089-1127; and M.E. Levine and J.L. Forrence, "Regulatory Capture, Public Interest, and the Public Agenda: Toward a Synthesis,” Journal of Law, Economics, and Organization, 6, April 1990, pp. 167-198.

${ }^{27}$ See J. E. Stiglitz, “Central Banking in a Democratic Society,” De Economist (Netherlands), 146(2), 1998, pp. 199-226. (Originally presented as 1997 Tinbergen Lecture, Amsterdam, October).
} 
underestimates the scope for government failure. It is all well and good to argue that government could in principle improve welfare. But what happens in practice?

Anyone who has watched the U.S. government in the last seven years is well aware not only of the possibility of government failure but also of its reality. In some cases it is a matter of incompetence, in others of corruption; in some cases it may be hard to distinguish the relative role played by each. Government programs can be subverted.

The analytic questions are, first, are these problems inevitable? Secondly, when they occur, are there corrective processes? Thirdly, are there some regulatory measures (and some regulatory processes) which are less likely to be subverted? Just as much of recent economic research has been directed at the question of how we mitigate the consequences of economic failure, we can ask, what can we do to mitigate the likelihood and consequences of government failure?

Government failure - at least on the scale that we have seen it in recent years - is not inevitable. Indeed, the Reinventing Government initiative showed that concerted efforts to improve the efficiency and responsiveness of government could succeed. Beyond that, some of the same reforms that work in the private sector are relevant in the public: increasing competitiveness and transparency, and improving incentive structures, where outputs can be reasonably well-defined and attributed to particular individuals.

So long as there is sufficient transparency and competition, there are corrective processes. Governments that fail will be replaced; they lose their credibility and legitimacy. To be sure, those in the political process try to reduce competitiveness (e.g. by gerrymandering) and to hide failures (through a lack of transparency) just as do those in markets.

Finally, some regulatory processes are more subjected to "public failure" than others, and part of the art of the design of regulatory regimes is to identify those which are less likely to be captured or abused. One of the arguments for disclosure requirements is that they are less subject to abuse, and one of the arguments against barter arrangements (zoning variances in return for providing certain public goods) is that they are never perfectly transparent and are therefore subject to abuse.

One reason for having multiple oversight (e.g. of banks or securities markets) is that it reduces the scope for capture. It means that even if there is a failure in one part of the regulatory system, there will not be in others. The SEC failed to take appropriate actions in the case of many of the abuses earlier in the decade, but fortunately New York State did (using the flexibility provided by the Martin Act). In some ways, our anti-trust framework provides a model for combating government failure (and it was designed with an awareness of the political pressures that are put on government not to take action): there are both civil and criminal actions; there is oversight by more than one federal agency and at both the federal and state levels. The larger the consequences of 
government failure and the larger the probability of government failure, the greater the value of multiple oversight. $^{28}$

\section{Applications}

In this section, we apply these general principles to three areas of regulations that are the subject of extensive current discussion.

\section{A. Sovereign Wealth Funds: Does ownership matter?}

Sovereign Wealth Funds are the funds of government assets that are being invested abroad. The oil exporters have accumulated hundreds of billions of dollars. They have been advised not to spend their money - to manage their wealth to take account of the variability of international prices and to mitigate Dutch disease problems. With oil prices soaring to $\$ 100$ a barrel, the magnitude of these funds have soared too.

The other group of countries with large sovereign funds is the developing countries that have had high savings rates and that have bought dollars to avoid currency appreciation. China has more than $\$ 1.3$ trillion in reserves and a national savings rate of $42 \%$. The amount in the reserves of various other Asian countries is now in the trillions. Singapore's Provident Fund has been built up with 42\% contributions from workers. It was only a matter of time before these countries figured out that holding dollar T-bills was a bad store of value-especially with the declining dollar.

These funds grabbed public attention when they bailed out Citibank and Merrill Lynch. They had billions in liquid assets and could act quickly. According to some Wall Street rumors, had they not bailed out these financial institutions, they would have gone under-or required a government bail-out. But not only did existing shareholders have to give up a significant fraction of their ownership share, collectively their ownership shares gave them effective control. Some began to fret: should government regulate these funds?

The G-8 and the IMF called for more transparency. They wanted to be sure that these funds had strictly commercial objectives. Norway's highly transparent funds were evidently unobjectionable-even though as a shareholder, Norway had often expressed its views about corporate governance, human rights, and the environment (views that went beyond strictly commercial concerns).

There was a certain naiveté—and hypocrisy —in these stances. Evidently, nontransparent hedge funds were permissible. No one knows who owns these hedge funds.

\footnotetext{
${ }^{28}$ The general theory is set forth in a series of papers with R. Sah: "Human Fallibility and Economic Organization,” American Economic Review, 75(2), May 1985, pp. 292-296; “The Architecture of Economic Systems: Hierarchies and Polyarchies,” American Economic Review, 76(4), September 1986, pp. 716-727; “Committees, Hierarchies and Polyarchies,” The Economic Journal, 98(391), June 1988, pp. 451-470; and “Qualitative Properties of Profit-Maximizing K-out-of-N Systems Subject to Two Kinds of Failure,” IEEE Transactions on Reliability, 37(5), December 1988, pp. 515-520.
} 
They could even be owned by a secret Cayman island corporation whose owners were the sovereign fund. Were the IMF and the G-8 simply asking the sovereign funds to act more obscurely indirectly through hedge funds? With the close connections of some in Western financial markets to these hedge funds, one could understand the rationale: increased fees for the hedge funds. But this was a hardly compelling basis of public policy. ${ }^{29}$ Defenders of the hedge funds say: but we know that hedge funds are commercially oriented. We don't know what motivates sovereign funds. They might have political objectives - that would be contrary to America's best interests. But if that worries one, one should be equally worried about the hedge funds. We don't know who owns them, and so we don't know what motivates them.

Most of the debate is motivated by fears. It is not that the sovereign funds have taken actions which are objectionable, which are motivated by any thing other than profit maximization. It is only that they might do so, and we need to take preventive action. Of course, no one wants to stop the funds. If the funds had not bailed out Citibank and Merrill, America's economic problems might have been even worse. Today's buzzword is transparency. What is demanded is more transparency.

What kind of transparency would make a difference? Should we take comfort that they say they are pursuing just commercial objectives? How can we be sure that they do what they say? What information would a disclosure of balance sheets make? We normally don't require such disclosures. Why here? ${ }^{30}$

Moreover, the pursuit of commercial objectives has never been a requirement for ownership in the past. Many a newspaper and TV has been bought not for commercial reasons but as a basis of advancing a political perspective.

What is clear is that the brouhaha over the sovereign funds is partly a fairly transparent form of new American protectionism and partly an attempt to shift attention from the failures of America: if America had saved more, and if its financial institutions had behaved better, it wouldn't have had to turn to these sovereign funds.

Nonetheless, the debate has served a salutary purpose: it has opened up the question, does ownership matter? For years, the IMF and the US Treasury have been telling developing countries to privatize their assets and to remove restrictions on foreign ownership. Many within the country were anxious about selling national assets. They were told: don't worry. The nationality of the owner doesn't matter. No objection was made even when a firmed owned by a foreign government bought an enterprise. But of course there can be a conflict of interest, as we have already noted, but they can arise whether the owner is domestic or foreign. For instance, private firms managing a

\footnotetext{
${ }^{29}$ One ex-Secretary of Treasury who has been among the most vociferous in calling for greater transparency of sovereign funds had resisted calls for greater transparency for hedge funds. In making his arguments, he has not usually disclosed that he has himself been working for a hedge fund.

${ }^{30}$ Market advocates would argue further that disclosure of the portfolio would make public the fruits of their research, undermining incentives to gather information, thereby decreasing the informational efficiency of the market. (These are the arguments that were put forward in defense of hedge fund secrecy.)
} 
country's natural resource seek to minimize the payments made to the government, while it is the nation's interests to have these payments maximized.

Underlying the objections to the sovereign funds is a simple fallacy. It is based on the hypothesis that (a) rational owners will desire firms to maximize the value of their firms; and (b) value maximization leads to social welfare maximization. Each of these hypotheses has been the subject of extensive research and has been shown to be true only under certain limiting conditions (e.g. a complete set of risk markets, no information asymmetries, perfectly competitive markets). ${ }^{31}$ Some have argued that competitive markets force firms to maximize value; if they do not, they will be taken over. But this too has been shown not to be true in general. ${ }^{32}$ Interestingly, many take-overs do not result in the increase in the value of the firm(s); they seem motivated by the hubris of the CEO of the taking over firm, who is willing to sacrifice the value of his firm for his personal gratification. ${ }^{33}$

There are certain circumstances when there are systematic conflicts between, say, what firms might do (whether a result of value maximization or not) and societal welfare that we impose regulations to constrain the behavior of firms. We restrict, for instance, their pollution.

Ownership matters, as we noted earlier, because it affects incentives for behaviors which are not in the social interest and we cannot adequately control behavior. But this is true whether the owner is a private American or a foreign government. In the one case, it is profit motives; in the other because there may be political motives. But if there is scope for behavior which is adverse to public interest, even well-motivated people may take adverse actions: those engaged in the sub-prime mortgage activities had ordinary motives of profit maximizing, some were not explicitly engaged in predatory lending, but simply had very bad judgments - they didn't understand the nature of risk. There may, nonetheless, be severe consequences for our economy. Such behavior should be proscribed.

In short, the debate about sovereign wealth funds highlights the limitations of our regulatory systems. If a sovereign wealth fund were to buy a pencil company, and, motivated by politics, decided to give away pencils as an act of friendship, no one would be concerned. If the firm is mismanaged and goes bankrupt, no one would be much concerned - anti-trust laws would have ensured that the firm is small, and if the economy is functioning well, those who lose their jobs would quickly find others. If a sovereign bought a bank and decided not to lend to a particularly country (whether it thought it a

\footnotetext{
${ }^{31}$ See, for instance, Sanford Grossman and J. E. Stiglitz, "On Value Maximization and Alternative Objectives of the Firm," Journal of Finance, 32(2), May 1977, pp. 389-402, and "Stockholder Unanimity in the Making of Production and Financial Decisions," Quarterly Journal of Economics, 94(3), May 1980, pp. 543-566.

${ }^{32}$ See, for instance, Sanford Grossman and Oliver Hart, and O. Hart, 1980. "Takeover Bids, the Free-rider Problem and the Theory of the Corporation," Bell Journal of Economics, 11(1), pp. 42-64; and "The Allocational Role of Takeover Bids in Situations of Asymmetric Information,” Journal of Finance, 36(2), 1981, pp. 253-70.

${ }^{33}$ This reinforces the conclusion: non-economic motives often play an important role in market economies.
} 
bad risk or a rogue state), it would have little economic consequence (though we might socially disapprove of this discrimination and might pass anti-discrimination laws), as long as there was a competitive banking system. Even if it shut down a plant and moved it overseas to create jobs in its own country, there would be little concern: new jobs would quickly be created here at home. But if our competition laws or other regulatory systems are not working well, then a firm owned by a sovereign fund - or a private firm - might take actions that are adverse to the public interest. Ownership does convey information; it may tell us about the likelihood of such actions being undertaken. In some circumstances, it may provide an additional rationale for regulatory scrutiny. But in only limited circumstances - such as those described earlier-where regulatory oversight is so impaired that appropriate actions cannot be taken in a timely way and where the consequences of the adverse actions cannot be easily repaired-is there a compelling case for ownership restrictions. But when ownership restrictions are thought warranted, they should be non-discriminatory. Sovereign funds might be restricted, but if so, hedge fund ownership should be as well, unless there is full transparency of the true owners of the hedge fund.

\section{B. Financial Sector Regulation}

During the Clinton Administration, I led a review of the Federal government's regulation of the financial sector, as part of Vice-President Gore’s “Reinventing Government” initiative. Our objective was to identify the objectives of regulation and to assess whether current regulations achieved those objectives in the most effective way. As a result of the review, we eliminated some regulations - such as those requiring notification of every installed ATM-but supported the continuation of others.

We identified five interrelated reasons for government intervention: (a) ensuring competition; (b) protecting consumers; (c) ensuring the safety and soundness of financial institutions and the financial system; (d) ensuring access; and (e) promoting macroeconomic stability and growth. The list includes concerns both about efficiency-market failures - and equity (without government regulation, certain groups may not have access to finance and may be exploited).

Competition is largely the responsibility of the Department of Justice, but there are distinctive characteristics of this market which require special attention or more specialized knowledge. ${ }^{34}$ The market is complex, in which while there may be a large number of banks, the number providing particular financial services—say, loans to small businesses in the State of Washington-may be very limited. There may also be complicated questions balancing out competition with other objectives (such as safety and soundness). ${ }^{35}$

Consumer protection. One of the concerns about the sub-prime mortgage crisis is that it would have been less severe had legislation or regulations to restrict predatory lending been adopted. At the time, some argued that the loose lending standards would enable

\footnotetext{
${ }^{34}$ This is one of those instances, noted earlier, where there is especial value to multiple oversights.

${ }^{35}$ Enhanced competition reduces profitability, making banks more vulnerable.
} 
more individuals to become homeowners. But it should have been clear that giving a loan to someone beyond their capacity to pay is not doing a favor. The main beneficiaries were those making the loans - there was even opposition to regulations requiring that lenders demonstrate that refinancing be in the interests of the borrower. But the debate surrounding these restrictions highlights some of the complexities of regulation: under the hypothesis that house prices would continue to go up, denying the poor the right to participate in this economic-give away would have been unfair. While the Ponzi scheme was working, some did benefit. Like any pyramid scheme, those who get in and out earlier can win. But government has the responsibility to see through the hype-it is arithmetically impossible for house prices to continue to rise while the incomes of most Americans are falling, unless the cost of capital continues to fall.

Consumer protection begins with disclosure-individuals should, for instance, know what interest rate they are paying on loans. It is clear that there are strong market forces moving in the opposite direction. Ensuring the safety and soundness of financial systems — so individuals know that when they put money into a bank they will be able to get it out - and ensuring competition can also be thought of as part of consumer protection. Even with regulation, of course, banks may go under, which is why deposit insurance is required. As I noted earlier, the argument that deposit insurance leads to moral hazard is largely (but not totally) misguided. Individuals do not have the capacity to inspect the books of the banks in which they are depositing, and it would be inefficient for each of them to do so. But the existence of deposit insurance does necessitate stronger bank regulation: the S \& L debacle arose in part because banks offered high interest rates. Depositors may have known that those high interest rates could only have been paid on the basis of risky loans, but because of deposit insurance they did not have to worry.

Restrictions on high interest rates have been opposed by advocates of liberalization; they point out that such interventions in the market deny access to loans by risky borrowers who would not otherwise have access to credit. But high interest rates can also arise as a result of exploitation of borrowers, especially ill-informed poor borrowers in noncompetitive markets; and the higher risk associated with higher interest rates has a cost to the public, with either implicit or explicit deposit insurance. (High interest rates lead to riskier behavior and have adverse selection effects.) There is a "balance" of concerns, in which by and large, I think such interest rate restrictions are desirable.

Safety and soundness. Regulations directed at ensuring the safety and soundness of the banking system illustrate many of the instruments discussed earlier in this paper. There are ownership restrictions - industrial firms cannot, in general, own banks (though in many other countries they can), nor can certain individuals of ill-repute. There are capital adequacy requirements - in effect ensuring that the bank has sufficient capital at risk that it would not undertake excessive risk and so the probability of bankruptcy is sufficiently low. But governments often forget these objectives when the economy faces a downturn and losses mount, and there is a need for an equity injection. With no other sources available, governments often provide the requisite equity. Unless they take over control of the bank, the incentive effects are nil, or may even be perverse. The original owners 
only worry about the loss of their own capital, not the capital provided by the bank. All the government is doing is providing up front some of the money that it would have provided in the event of a crisis.

Capital adequacy standards that are appropriately risk adjusted can help undo the distortions associated with government deposit insurance and provide incentives for banks to undertake less risk, thus reducing the likelihood of a bank failure. The problem in the past is that the risk adjustments actually distorted bank behavior and contributed even to the contraction of credit availability. A key error, for instance, made by the Fed in the 1980s was to treat long term government bonds as if they were safe; there might not have been any credit risk, but there was still market risk. This encouraged banks to buy long term government bonds - and to make fewer loans. Accounting failures also contributed - the banks were not forced to set aside a reserve to reflect the risk of a fall in price. They could book the entire gap between the long term interest rate and the short term interest rates at which they borrowed as profit, even though the reason for this gap was market expectation of a fall in the bond price.

In many countries, restrictions on bank portfolios have played an important role. Speculative real estate lending has been the basis of many an economic downturn, and some regulatory authorities have accordingly restricted such lending (and insisted on high collateral standards). (In the case of Thailand, they were concerned both with development and stability; they hoped that by restricting speculative real estate lending, more funds would go into more productive investments, generating employment.) Ironically, the IMF (supported by the U.S.) was highly critical of such restrictions. If the market demanded the construction of empty office buildings, rather than investments in productive factories generating employment, one should not interfere with the market. Under pressure, Thailand abandoned some of these prudential regulations, and this contributed to the crisis that the country faced a few years later.

One of the many problems with standard bank regulations (Basel I) was that they focused on risk, asset by asset; they didn't take into account correlations. That was why there was hope that Basel II, based on banks’ own risk management systems and credit rating agencies, would be a major improvement. After the current crisis, it is clear that Basel II is dead. The banks' risk management systems were badly flawed-evidently, the banks did not understand correlated risks, let alone fat-tailed distributions. The rating agencies (once again) were even worse, though this time there is evidence not only of ordinary incompetence: there was also a serious problem with incentives.

An important part of any regulatory system is information disclosures and accounting standards: regulations requiring banks to mark their assets to market are viewed as important, in providing depositors (and others dealing with the bank) better information about the bank's financial position. It can also avoid the perverse effects of not marking to market, which can encourage excessive risk taking. Banks can buy a set of risky assets, knowing that it can sell those that do well—reflecting the profits in its accounts; but hold on to the assets that are making a loss. Yet marking to market can also have other real and adverse effects. If markets exhibit irrational pessimism, marking to market 
may in a downturn force banks to acquire new equity injections-or force it to reduce outstanding loans. Poorly designed regulation can be pro-cyclical, exacerbating economic fluctuations. As we noted above, the decision of the Fed under Greenspan to treat long term government bonds as "safe" and not requiring them to set aside reserves played a large role in creating the recession of 1991.

Some have argued that disclosure is all that is required. For the government to provide deposit insurance contributes to moral hazard, because depositors will not take due care in deciding where to put their money. But as noted earlier, all countries have, in effect, deposit insurance: when a crisis hits, depositors will be bailed out. Moreover, information is a public good. It makes no sense for every individual to evaluate for himself the credit worthiness of each bank-even if it were possible for him to do so; and as we explained, there are real problems in market based certification.

Ensuring Access. These include regulations against discrimination and redlining and the Community Reinvestment Act, requiring banks to lend a certain fraction of their portfolio to underserved communities. ${ }^{36}$ Earlier laws, restricting interstate banking, had a similar motivation: there was a worry that New York banks would garner all the deposits but then divert the money back to the East Coast money centers. (In many developing countries, similar concerns are raised today: foreign banks are more likely to lend to multinationals and large domestic firms and less to domestic small and medium sized enterprises. Modern banking theory, which sees banks as processing information, assessing credit worthiness and monitoring, provides an explanation for these lending patterns.) CRA lending requirements have been successful in extending access to credit.

Many developing countries face a more general problem: banks prefer to lend to the government or to hold money abroad (speculating on a capital gain), rather than to lend money at home, especially to small and medium sized enterprises. In short, banks are not performing the role that they ought to perform. Several policies have been proposed for addressing the problem. One is to change incentives, e.g. by taxing at a high rate capital gains on foreign exchange speculation. Governments typically have large deposits. They can link where they hold deposits to bank performance: banks that lend to small and medium sized enterprises at low margins will get more government deposits. A second policy is regulatory: not allowing banks to hold government paper. If they wish to provide money to the government, they can do so, but they would get only a small service fee for providing depository services. (Government can, alternatively, provide direct competition to the private sector.) Generalized CRA requirements-requiring banks to lend minimal fractions to small and medium sized enterprises or to the rural sector-may also help.

The argument for these lending mandates is that the private sector is more able to make risk judgments, untainted by political connections, than say a development bank or a government agency. Within the rural sector, they will be able to find good borrowers. Such mandates and restrictions may lower short run returns (though not necessarily long

\footnotetext{
${ }^{36}$ Underlying these (and some of the other restrictions described earlier) is a simple notion: there is a discrepancy between the private and social returns to lending.
} 
run returns, as banks learn how to lend in each of these markets). Obviously, if excessive, these mandates will lower profitability to the point that there will be exit from the industry, but it appears in most cases that the value of a bank franchise (including right to access the funds of the Central Bank) are sufficiently great that this has not occurred.

\section{Macrostability}

Many of the regulations discussed so far have macro-economic implications. Safety and soundness focuses on the ability of individual banks to repay amounts deposited. But when risks are correlated, if many banks have a problem, the economy risks slipping into a recession. Without access to credit, it is hard for an economy to function.

Policies which make sense if an individual bank faces a problem do not make sense if all banks face problems. If only one bank is in trouble, regulators can be tough and refuse forbearance; but if many banks face difficulties, such an approach may force the economy into a deep downturn.

Similarly, regulatory rules have to be sensitive to their cyclical implications. There is worry, for instance, that strict enforcement of high (and non-cyclically adjusted) capital adequacy requirements can act as an automatic destabilizer.

\section{Greenhouse Gas Emissions}

The third example concerns greenhouse gas emissions which contribute to global warming. The policy debate has centered on emission taxes versus cap and trade systems. When the caps (the targets) are auctioned, then the two systems are almost equivalent. In one case, the government is setting a quantity and letting the price adjust; in the other it is setting a price and letting the quantity adjust. If the government had good information about the demand curve, then the two would be perfectly equivalent. In practice, either price or quantity will adjust over time (as we have noted earlier), in response to success in achieving the objective of ultimate interest, overall concentration of atmospheric greenhouse gases (or even more directly, change in temperature). One widely discussed proposal is the safety valve, which is a mixture of a price and quantity system: a quantity constraint, provided the price does not exceed a particular level, after which it becomes a price intervention. This has the short run advantage of limiting riskfirms know the maximum price that they will have to pay for emissions; and it provides the basis of a political agreement based on different perceptions-many environmentalists claim the cost of mitigation is low, and at the same time they want strict emission constraints. If they are correct, then the safety valve will never have to be used.

Different systems have different distributive consequences. When the international community grants a particular cap to a country, it is as if it grants it a cash-equivalent 
endowment (assuming emission permits are tradable). This is one of the reasons the debate is so contentious. The Kyoto system gave more emission rights to those countries that were emitting more; those who had polluted more in the past were given more cash, a peculiar policy, to say the least. The developing countries argue that, if anything, those who have polluted more in the past should have less pollution rights going forward. They have already used up their "share" of the global atmosphere.

The international distributive consequences of an agreement of a common tax rate, with the proceeds kept within each country, are likely to be small. Roughly, it is just the difference between the difference in the two Harberger triangles (that associated with the emissions tax, and that associated with the tax(es) that it replaces). There are, of course, large distributive consequences for different sectors. The cap and trade system offsets these by providing emission rights to past polluters. But the same equity concerns raised earlier arise. Moreover, it sets the stage for high levels of corruption: in some countries, it will be outright; in the more advanced industrial countries, it will be more subtle, with campaign contributions designed to affect the rules by which targets are set in ways which favor some (obviously, at the expense of others). ${ }^{37}$

While there is a consensus that, setting aside the distributive consequences, both cap and trade and a carbon tax, if universally applied, could lead to efficient outcomes, there is a growing consensus behind additional regulatory measures. The EU has imposed renewable energy mandates, the U.S. CAFE standards, and everywhere there is discussion of imposing other controls, such as on coal fired generating plants. Why, one might ask, should we resort to these "distorting” regulations when we have at hand an efficient mechanism for reducing emissions? The regulatory interventions create, in effect, a system which taxes emissions at different rates in different sectors. Part of the reason is concern about the distributive consequences of the large reductions in emissions that are required. To elicit the required behavioral changes, the explicit or implicit taxes on emissions will be very high-beyond levels that are likely to be politically acceptable. This in part may be because market participants are myopic. They see upfront costs more clearly than they do costs down the line; their implicit discount rate seems "irrationally" high. A more fuel efficient car which, at reasonable discount rates, is less expensive will not be bought because its up front price is higher. Many firms similarly respond to current patterns of consumption-in the 1990s, American automobile firms did not diversify their portfolio but rather concentrated their attention on the SUV's then in fashion. If one "forces" through regulation large behavioral changes in certain key sectors, the burden on the remaining sectors — changes that have to be accomplished through taxes - is reduced. The seeming cost of mitigation, ${ }^{38}$ and probably the actual cost as well, would appear to be lower. There is a more general point: typically optimal tax systems (designed either to raise a fixed revenue or to achieve a given reduction in emissions) are differentiated and non-linear.

\footnotetext{
${ }^{37}$ This is an example of how the form of government intervention may affect the likelihood of government failure.

${ }^{38}$ To critics of these regulatory approaches, the lack of transparency is itself one of the main criticisms.
} 


\section{CONCLUDING REMARKS}

The Arrow-Debreu model set forth a set of conditions under which Adam Smith's invisible hand worked perfectly; no government intervention is required. But the conditions required - not just the absence of externalities, public goods, and perfect competition, but also perfect information, a complete set of markets, including markets for risk, and no (endogenous) innovation-has meant that the model has been most useful in providing a taxonomy for why government intervention is required. Many economists, still in love with the price system, leapt to the conclusion that the government should only intervene through simple, linear taxes and subsidies. But, alas, for many of the same reasons that markets fail, so too simple price interventions are, in general, not optimal. More complicated regulatory interventions are, in general, required. In this paper, I have tried to outline some of the critical issues in the design of regulatory systems. The question today is not whether to regulate, or even whether we have overregulated - the sub-prime mortgage crisis suggests a problem of under regulation-but rather, if we have designed a regulatory system which is as efficient and equitable as it could be. 